MIDAS

Museus e estudos interdisciplinares

$12 \mid 2020$

Varia

\title{
Building the field of museum studies in Portugal: the role of publications
}

A construção da museologia como campo de estudos em Portugal: o papel das publicações

\section{Ana Carvalho}

\section{CpenEdition}

\section{Journals}

Electronic version

URL: https://journals.openedition.org/midas/2611

DOI: 10.4000/midas.2611

ISSN: 2182-9543

\section{Publisher:}

Alice Semedo, Paulo Simões Rodrigues, Pedro Casaleiro, Raquel Henriques da Silva, Ana Carvalho

\section{Electronic reference}

Ana Carvalho, "Building the field of museum studies in Portugal: the role of publications", MIDAS

[Online], 12 | 2020, Online since 15 December 2020, connection on 05 March 2022. URL: http:// journals.openedition.org/midas/2611 ; DOl: https://doi.org/10.4000/midas.2611

This text was automatically generated on 5 March 2022.

\section{c) (i)(2)}

Midas is licensed under a Creative Commons Attribution-NonCommercial-ShareAlike 3.0 International License 


\title{
Building the field of museum studies in Portugal: the role of publications
}

\author{
A construção da museologia como campo de estudos em Portugal: o papel das \\ publicações
}

Ana Carvalho

\section{EDITOR'S NOTE}

Artigo recebido a 17.09.2019

Aprovado para publicação a 23.07.2020

\section{Introduction ${ }^{1}$}

1 Museology (or museum studies) is a field of research and practice that is still evolving and affirming itself. The term 'museology' is documented as early as 1839 , but its wider use had to wait until the 1950's onwards (Schiele 2012). There are, however, some distinctions to be made regarding interpretation of the term. In Anglo-Saxon countries, for instance, the term 'museum studies' has been preferred. Appropriations of the term are diverse and not always consensual, depending on context, partly resulting from the field's own heterogeneous nature (Schiele 2012; Mairesse 2016). ${ }^{2}$ In this article we do not distinguish between museology and museum studies - they have here the same meaning, i.e., a research field which on the whole aims to study the museum, generally considered, paraphrasing the Canadian Bernard Schiele $(2012,88)$; furthermore, it is a hybrid and heterogeneous field, with fluid frontiers, built on methods and contributions from several areas of knowledge. Now that, apparently, museology no longer aspires to be seen as an autonomous scientific discipline (Schiele 2012; Mairesse 2016), an aspiration that was discussed mainly from the 1970's on ${ }^{3}$, it has become a multidisciplinary and interdisciplinary research field, open to dialogue with other branches of knowledge and to the plurality of reflexive approaches regarding the 
understanding of what a museum is (Macdonald 2006). On the other hand, the expansion of museum studies has seen a dilution of the polarized tension between theory and practice, moving towards a more productive relationship between museums and academia (in rhetoric at least). The complexity of the museum as an object of study seems to require greater theoretical sophistication and methodological expansion, as well as better exchange and dialogue between practical and theoretical problems, in the assumption that both modes of knowledge can feed off and shape each other (Macdonald 2006). ${ }^{4}$

2 Just as the definition of museology has undergone several reformulations and is still open to discussion, so the concept of 'museum' has seen several proposals for redefinition, considering the need for a readjustment of the role of museums regarding the challenges faced by society in the $21^{\text {st }}$ century (Sandahl 2019; Carvalho 2019).

3 The role of universities in creating specialized museology courses (post-graduation, masters and doctorates) has been crucial for the recognition of museum studies as an area of study. In Europe, universities started contributing more decisively to training in museology after World War II (Lorente 2012) - at different paces, according to geography and context, varying among countries. ${ }^{5}$ In the United Kingdom, Leicester University created a department for museum studies in 1966. In France, the Cours de Muséologie Générale Contemporaine was offered from 1971 to 1982, lectured by GeorgesHenri Rivière (1897-1985) at the University of Paris I; and in the Netherlands the Reinwardt Academy (Amsterdam University of the Arts) in 1992 started offering postgraduate studies in museology - just to mention some examples. ${ }^{6}$ In Portugal, postgraduate studies in museology began to appear mainly in the 1990's.

The growing bibliography concerning museology and the appearance of specialized journals are also among the ways of constructing the field, since they ensure visibility and access to the knowledge produced, in addition to helping articulate diverse views, perspectives and proposals, both theoretical and practical, thus strengthening its development. In other words: publications in general, and scientific periodicals in particular, contribute to the evolution of a given field of study (Nunes 2001).

5 The global international panorama illustrates the appearance and growth of museology-related publications (Lorente 2013); but such trajectory is still to analyse in the case of Portugal. Thus, this article examines the role of publications in building museology as a field of study. We have selected key moments and initiatives which reflect the evolution of the publishing landscape, its contexts and main protagonists. In this context, we have looked at a time frame set between the 1990's and the present day, underlining dynamics, relationships and trends, although is not intended to be exhaustive.

6 The choice of the 1990's as a landmark in this trajectory is due to two main factors, both introducing changes which impact the museological landscape and its evolution in the decades that followed. One of them is the contribution of Portuguese universities which, in that decade, began to offer post-graduate courses in museology. Another distinctive sign of change has to do with the gradual importance and autonomy of the museum sector (Semedo 2004), with growing evidence in public policy. One reflection of this fact was the creation, in 1991, of the Instituto Português de Museus (IPM), a public organization aimed at museums and the implementation of a museum policy. 
7 In such framework is not to ignore the sociocultural transformations experienced by Portuguese society in previous decades, which significantly impacted the museological landscape, as a consequence of the 1974 Revolution. The museological explosion, especially from the 1980's on, marked by municipal initiatives, the associative movement for the defence of cultural heritage, and the influence of international reflection on museology - are some of the factors that cannot be separated from the transformations which the museological panorama experienced from 1974 to 1990 , being the subject of various studies (Camacho 1999; Semedo 2004; Raposo 2014).

The methodology adopted in this article included literature review and empirical knowledge on the subject matter. The following analysis notes the role of Portuguese universities in museology training, in a context of museological explosion. In addition, examines various contexts and actors, which results in a diverse ensemble of editorial projects: from professional and associative periodicals, to scientific and institutional journals, publications from universities, theses publishing and technical publications, among others.

\section{The museological explosion and the need for training}

In Portugal, museum curators traditionally received training in the museum setting. This panorama changed only when post-graduate and master's degree courses were created in the universities, starting in the early 1990's. ${ }^{7}$ The museum curator course at the Museu Nacional de Arte Antiga (Lisbon) was created in 1965 and functioned until 1975 (Gouveia (1986) 1991).8 Other training initiatives appeared later, namely the courses coordinated by the Instituto Português do Património Cultural (IPPC), between 1981-1982 and 1984-1985, and the course coordinated by the Associação Portuguesa de Museologia (APOM) and by the Instituto de Formação Profissional, at the Escola Superior de Belas Artes, from 1988 to 1990 (Semedo 2004). These experiences, however, were short-lived.

10 The first post-graduate training initiative in a university context took place in 1989 with a course in Social Museology at the Universidade Autónoma de Lisboa (Carvalho 2015), later transferred, in 1991, to the Universidade Lusófona. In the years that followed, other universities stepped forward and created their own courses (postgraduation and master's) in museology, on which stand out in a first phase: Universidade Nova, Universidade do Porto, Universidade de Coimbra and Universidade de Évora.

11 From the 1990's onwards, there was a crescendo in the offer of post-graduate studies in this area, a trend that only came to be moderated by the effects of the post-2008 financial crisis, later exacerbated by the Portuguese sovereign debt crisis beginning in 2011. Universities felt these impacts, namely through administrative restructuring, leading to the reformulation of this academic area, including its curricula. ${ }^{9}$

Among other factors, the entry of museology training into Portuguese universities can be explained by the need to train professionals, given the boom in the creation of museums seen after 1974. This museological explosion is also coincident with the increased number of museums occurring all over the world, especially since the 1970's (Fyfe 2006). The growing demand by professionals - some of them already working in museums - for specialized and updated training in museology, which occurred in the 
1990's, significantly impacted the training options offered by universities (Carvalho 2013), thus confirming the relation between the museums boom and the need for training felt on the field. In a wider perspective, we should note the context of change observed in universities in the 1980's and '90's, namely the emphasis placed on modernization and the need for better articulation between universities and the labour market (Semedo 2013).

\section{Initiation to museology} Trindade 1993), promoted by Universidade Aberta, marked the publishing landscape in this area as the first manual of this kind to appear in Portugal. Its edition expressed the urgency of disseminating know-how and the need to 'to embark on a long effort of sensitization, qualification, specialized training of those whose dedicated commitment or undeniable calling will have responsibilities in the matters of museology', in the words of the anthropologist Maria Beatriz Rocha-Trindade (1993, 17-18). This publication highlights the need for the qualification of human resources - one of the challenges identified as problematic in the sector (Silva 2000) -, the investment in training and in the dissemination of knowledge applied to museums, fundamental aspects to leverage the promising development of Portuguese museums in the 1990's. $20^{\text {th }}$ century, evidencing an history to be told and to expand, and giving a note on contemporary museology, through emerging experiences of local scope (e.g. Ecomuseu Municipal do Seixal, Museu de Mértola, Museu Municipal de Vila Franca de Xira, among others). archaeology, natural history, science and technology museums. On the other hand, the manual introduced practical guidelines for initiation in various areas of museum work (e.g. inventory, display, organization and space functions, conservation and security, among others).

16 At a time when the bibliography on museology in Portugal was scarce (Silva 1999), when the translation of foreign literature in this area was not explored - an aspect that still prevails today - this manual is relevant to the extent that it corresponds to an attempt to fill the gap in unpublished basic texts. However, it turned out to be an isolated initiative, without opening the way for the development of a book series or collection.

\section{Signs of change at the turn of the millennium}

17 The first decade of the $21^{\text {st }}$ century saw more developments occurring, through publishing and the creation of spaces for dissemination, thereby enabling better structured thinking about the museum sector. At the outset of the decade, we note the publication of a thematic issue of the journal Museología (edited by the Spanish Association of Museologists), dedicated to museums and museology in Portugal. Coordinated by Maria da Luz Nolasco Cardoso (from Museu de Aveiro), this Spanishlanguage issue proposed a 'balance between the past and the future of museums, as 
well as museum and heritage policies pursued in Portugal' (Nolasco 2000, 8). Six major vectors of reflection stand out among the themes approached: audiences, in a sociological perspective of culture; new communication technologies, stressing the promotion of access to the collections (digitization, management); museums and local identity, highlighting museological experiences under the tutelage of municipal administration; the contribution of architecture and the evolving needs of museums, both in terms of functions and regarding transformations of space (expansions, renovations, new buildings); museums created by foundations, with a discussion of experiences and specificities; and, finally, a focus on the area of conservation and restoration, acknowledging it as an autonomous scientific discipline.

\section{Introduction of new formats}

The journal Museologia - An International Journal of Museology (2000-2003) was the first periodical to establish itself as a scientific journal in Portugal specializing in the museology of science and technology. The entity in charge was the Museu de Ciência da Universidade de Lisboa (nowadays called Museu Nacional de História Natural e da Ciência) and its coordinators were Fernando Bragança Gil (1927-2009), then the museum's director, and Marta C. Lourenço, as an editorial assistant. It sought to publish original scientific papers (with peer review) in English, Portuguese, French and Spanish, to reflect on contemporary research on museology. One novelty was its international scope, which could be seen in the line-up of its editorial committee ${ }^{10}$ and the geographic representation given by the articles it published. Only three printed issues saw the light of day; the last two corresponded in fact to the minutes edition from the first and second conferences of the International Committee of ICOM for University Museums and Collections (UMAC) - created in June of 2000 - which took place in Barcelona (2001) and in Sydney and Canberra (2002), respectively.

\section{Institutionalization: on course toward specialization}

Regarding public organisations involved in museum policies, the second half of the 2000's saw the appearance of Museologia.pt (2007-2011), a journal which specialized in museums and museology - institutional in nature, and with a national scope. ${ }^{11}$ Under the responsibility of then-new Instituto dos Museus e da Conservação - IMC (directed by Manuel Bairrão Oleiro), this annual, printed publication, coordinated by Clara Frayão Camacho (the Institute's sub-director), sought 'to contribute to stimulate debate, enrich the specialized bibliography, and encourage information and novelty' (Camacho, 2007, VI). This meant a recognition of the need to overcome the scarcity of specialized journals in museology.

Structured in a closed system of contributors, Museologia.pt included an editorial board with representatives from several museums and Portuguese universities. ${ }^{12}$ Five issues came out, organized around five main sections: 'projects and experiences', 'exhibitions', 'history and memories', 'dossier'13 and 'international'. The editorial project was assumed as a forum for debate, reflection, and the dissemination of innovative practices and trends. It stressed the importance of interdisciplinarity in museology and the need for an international perspective, namely in what concerns museum policies (Camacho 2007). A new political cycle, however, led to the 
restructuring and merging of public organizations in the central administration, resulting in the extinction of IMC and the end of this editorial project, with a last issue in 2011.

21 A new organization, Direção-Geral do Património Cultural (DGPC), created in 2012 and directed by Isabel Cordeiro, launched in 2013 a new institutional publication called RP Revista Património, embracing a multidisciplinary approach. This publication was the successor of two different earlier editorial projects: Museologia.pt and the journal Estudos/Património ${ }^{14}$. RP - Revista Património follows, in general, some of the main characteristics of its predecessors: it was yearly printed (in a partnership with Imprensa Nacional-Casa da Moeda) and relied on a closed system of contributors. ${ }^{15}$

Directed by the architect Manuel Lacerda (head of Divisão de Documentação, Comunicação e Informática), and coordinated by the historian Deolinda Folgado (head of Divisão do património móvel, imóvel e imaterial), the journal encompasses the role of presenting and disseminating the DGPC work and activities and, more broadly, the thinking that shapes official heritage policy. Its general goal was to reflect 'the current complexity of cultural heritage and the different perspectives with which it is faced nowadays' (Lacerda 2013, 1). In addition to the articles by professionals belonging to DGPC, there is a considerable external contribution by university researchers and professors producing knowledge on cultural heritage from different disciplinary angles. The international approach is not ignored, including, for example, occasional contributions by professionals and researchers from similar organizations in Spain, although not exclusively. Each issue is guided by a central theme ${ }^{16}$, including other sections: 'thought', 'projects', 'opinion' and 'society'. To a certain extent, this publication reproduces the relative weights of the different sectors present in this organization (architectural and archaeological heritage, museums, conservation and restoration, and cultural heritage, both tangible and intangible). Although museums were included in the array of contents, the need to cover a wide range of areas in one single journal resulted in each of them receiving less space. This was probably one of the reasons why, seven years after the end of Museologia.pt, a new institutional journal emerged (RM - Revista de Museus), to be dedicated entirely to museums.

The journal RM - Revista de Museus (2018-) is framed as a new editorial project, under the direction of David Santos, who was at the time the deputy director-general of DGPC, together with Clara Frayão Camacho (scientific coordination) and Fátima Roque (editorial coordination), supported by an external editorial board ${ }^{17}$. As David Santos underlined in his first editorial, 'this is a publication which will seek not only to reflect, but also to introduce some of the themes shaping the contemporary experience of the life of museums [...]' (Santos 2018, 5). Like the journals museologia.pt and Património, the RM - Revista de Museus, retains the printed format, the annual periodicity, the selection of articles by invitation, as well as the choice of a central theme ${ }^{18}$. As form goes, this journal distances itself from museologia.pt, in particular regarding the care given to aesthetics, which can be observed from the central role played by illustrations in every issue. In fact, this distinctive trait is clearly assumed:

[...] this annual publication aims to affirm the principle of museological analysis, while at the same time affirming itself as an object of aesthetical seduction. Thus, the critical and reflexive effort is linked to the ludic nature of a journal that dares present itself as a collectible object as well, for those essential reasons which lead 
humans to cultivate what they intend to preserve for future memory. (Santos 2018,

5) initiative, when compared to the projects already mentioned. Anchored to the project of creating a nationwide museum network, the Portuguese Network of Museums - RPM (2000), this quarterly bulletin (both printed and digital) sought 'to promote in a systematic way the circulation of information related to museum practices, and to encourage new channels of communication among museums' (Camacho 2001, 1). Initiated by Clara Frayão Camacho, then the coordinator of $\mathrm{RPM}^{19}$, it coexisted as a complement to the journal Museologia.pt under the Instituto dos Museus e da Conservação (IMC) management. The bulletin was, over a ten-year period, a systematic channel of information concerning the museological activity being developed at the time. It was a structural element of the RPM project, as a tool to promote museum networking. Following the extinction of IMC and the creation of a new institutional organization - DGPC -, the RPM remained active but lost centrality and relevance in the new organizational context. The weakening of RPM's capacities after 2011 can be observed, too, with the end of its bulletin. This also indicates a disinvestment in the circulation and sharing of information among professionals and museums, implying on a more global scale the dilution of the RPM initial programmatic guidelines (Camacho 2020).

\section{Associative contributions}

If we consider the panorama of professional associations, the promotion of dissemination channels among associates was still incipient in the early 2000's, suffering to this day from uneven, irregular rhythms. However, one must highlight APOM's initiative to create a semestral (printed) journal in 2003 - Lugar em Aberto Revista da APOM. ${ }^{20}$ Coordinated by António Nabais, then presiding over APOM, the first issue organized a reflection around museum functions - educational service, exhibition and programming - and intended to continue along these lines in subsequent issues by focusing on research, inventory and preventive conservation. But in fact, only this first issue saw the light of day. Nonetheless, Lugar em Aberto confirmed the effort to publish texts with the aim of being references in their respective areas. This aim informed the publication, and thus to avoid being a mere tool for disseminating associative activity per se, which in this case was in fact diminutive. Particular attention was given to the introduction of a section dedicated to listing dissertations and theses 'of interest to museology' produced up to that moment in universities inside and outside Portugal which highlights the need to systematize information and its dissemination. 

appeared in 2008. It was regularly issued until 2014, totalling 24 issues in digital format exclusively. ${ }^{22}$ Coordinated by the museologist Maria Vlachou, the bulletin's structure was redesigned and expanded in relation to its first series. Association-related information was still present, but new possibilities were opened for different content by introducing new sections ('article', 'opinions', 'interview with', 'new, recent and renovated', among others).

31 The third series (Boletim ICOM Portugal) was launched in 2014 and came out regularly until June 2018, reaching a total of ten issues published. ${ }^{23}$ The bulletin, edited by the museologist Ana Carvalho, followed the general structure of the previous series, but it was expanded. In terms of form, new sections were designed ('editorial', 'a message from the president', 'museums \& people', 'in brief', 'news ICOM'). Each issue became subordinated to a chosen central theme $\mathrm{e}^{24}$, including greater articulation with central ICOM, namely regarding themes related to the annual celebration of the International Museum Day. ${ }^{25}$

In general terms, when we analyse periodic publishing by professional associations, we should highlight at least two aspects which have conditioned this activity. One is the fact that creating communication tools with associates is apparently considered a secondary aspect, instead of being assumed as a line of action. On the other hand, publishing bulletins or similar tools is strongly dependent on voluntary action of such associative movements and on its leadership cycles.

\section{Other dynamics}

Editorial dynamics coming from regional contexts are also noteworthy, e.g., the journals Musa and Museal which, although their transitory, illustrate the need to create spaces of reflection that present and evidence museum-related studies and experiences, within a more specific territorial context.

The journal Musa: Museus, Arqueologia \& Outros Patrimónios appeared in 2004, bearing the seal of the Fórum Intermuseus do Distrito de Setúbal and of the Museu de Arqueologia e Etnografia do Distrito de Setúbal, a Forum that assumed itself as the first regional-level museum network. This publication was instrumental in validating the idea of a common project among the various municipalities within the Setúbal district. Coordinated by Joaquina Soares (Museu de Arqueologia e Etnografia do Distrito de Setúbal), the publication was organized around the theme of museums, including related areas, and presenting differentiated quality content. Some texts were contributions which relied on the dissemination of the research carried out, while others were more informative regarding the characteristics of the museological reality

MIDAS, 12 | 2020 
at stake. Initially intended to have annual periodicity, the journal in fact published only three issues in total, at irregular intervals (2004, 2007 and 2010). It is worth noting, nevertheless, the aggregating capacity of this kind of editorial projects, based on institutional cooperation and benefiting from shared interests of professionals and museums/institutions, thus moving beyond the particular agenda of each municipality. The journal Museal (2006-2009) was an initiative promoted by the Museu Municipal de Faro, whose regional scope did not prevent it from reaching nationwide scope. Coordinated by Dália Paulo, who was at the time the museum's director, this printed publication came out once a year. ${ }^{26}$ Four thematic issues saw the light of day, concerning a diverse scope of topics: the museum landscape in the Algarve region ( $A$ Realidade Museológica no Algarve: Perspectivas para o Séc. XXI, 2006); preventive conservation (Conservação Preventiva: Prevenir para Preservar o Património Museológico, 2007); museums and frontiers (Museus de Fronteira: Fronteira e o Museu, 2008); and, finally, museum branches and sustainability (Núcleos Museológicos: Que Sustentabilidade?, 2009), the latter mostly consisting of the published minutes of the meeting of the same name, which took place in Faro in 2008.

In 2013, the journal Argos was launched. Edited by the Museu Marítimo de Ílhavo, this editorial project goes beyond the local and regional context and affirms itself as a thematic journal linked to maritime culture, on the national and international levels ${ }^{27}$, even though it remains intrinsically associated with this municipal museum's own cultural project. Álvaro Garrido, the journal's coordinator who at the time served as museum director, states in the following terms the motivations behind its creation:

Although maritime museology does not exist as an institutional field in Portugal, it

is important to build networks, share the best projects, extol the experiences most

rooted in the communities and highlight those organizations which mobilize

creative concepts around maritime heritage. (Garrido 2015, 5)

This yearly printed journal relies on a closed system of contributors, having put out seven issues so far. Not being limited to museology, it brings together inputs from various fields of study, thus helping form a space for debate and reflection around the challenges faced in this specific area of analysis: museums connected to maritime culture.

Aside from each project's specific constraints, difficulties are often observed in keeping up publications of this type. They may suffer breaks in their regularity, and even disappear altogether - the kind of problem that similar initiatives in other areas also face. Among other factors, we can mention: the (un)sustainability of projects, usually dependent on support from the local administration (or other public instances), vulnerable to political cycles, and from the personalities who impel them; the difficulty of distribution in commercial settings (as is the case with the publications mentioned above); the lack of promotion and dissemination mechanisms for the journals; and the challenge of constantly feeding the proposed editorial guidelines with relevant and reflective content.

\section{Periodic edition by museums: an intermittent dimension}

Editorial action undertaken by museums is not to be ignored. We should stress the growth of periodic publications promoted by museums, usually centred on studies of 
the collections and/or heritage under their tutelage, and mostly related to each museum's cultural project. However, they are generally lacking in regularity. A more profound analysis would lie outside the scope of this article, but we can refer some examples: the Boletim Trimestral do Ecomuseu Municipal do Seixal (1996-2011), quite longlasting, the Cenáculo - Boletim On-line do Museu de Évora (2007, 2007, 2008, 2010), and also the Cadernos do Museu - Publicação Periódica do Museu da Ruralidade (2015-2017). ${ }^{28} \mathrm{We}$ should also note the journal Museu edited by the Círculo Dr. José de Figueiredo (Grupo dos Amigos do Museu Nacional de Soares dos Reis), which began to be published in 1942, and despite some interruptions it still remains being edited.

On the other hand, investments made on the edition of exhibition catalogues should also be highlighted, since it has been one of main ways - sometimes the only one - of disseminating studies about collections and their formation, as well as research work done in the museums' context. ${ }^{29}$

\section{Affirmation via academia}

41 It is mostly in this last decade that we have seen a greater emphasis on edition on the part of universities which offer courses in museology. These new dynamics and (re)positioning are directly linked to the evolution of training itself, whose offer has been extended to doctoral and post-doctoral studies. While the increased availability of post-graduate training in museology is linked to a law on museum careers in 2001, which began to require a post-graduate or master' degree for those wishing to become museum curators (Law-Decree n.. 55/2001, article 3), the offer of doctoral-level courses $^{30}$ reflects the dynamics of universities themselves, whose growth was encouraged by offering third-cycle studies. ${ }^{31}$ One consequence of this evolution was a clearer process of differentiation, by each university, to give visibility to the scientific outputs of its researchers. This phenomenon is also consistent with the reorganization of scientific policies at the national level (as a way of responding to the crisis) and the encouragement of 'competitiveness' and performance evaluation in the research centres associated with the masters' and doctoral studies on offer. In such context, it is worth noting the case of Universidade Nova de Lisboa, Universidade do Porto and Universidade Lusófona de Humanidades e Tecnologias.

Concerning Universidade Nova de Lisboa (Faculdade de Ciências Sociais e Humanas), it is noteworthy the printed edition of a thematic issue around the topic 'museums and research' (Nr. 8, 2011), coordinated by Raquel Henriques da Silva, from the Revista de História da Arte edited by Instituto de História da Arte. The articles in this issue are, for the most part, grounded on research produced by this Institute under the scope of 'museum studies' (MuSt). In addition to a central core of articles, the issue focuses on texts written about past exhibitions, gives an account of ongoing projects, and adds a section which lists all the dissertations and theses made in museum studies up to 2011. The same logic presides over the Institute's investment in the creation of the Arte $e$ Museus collection (2013), by publishing masters' dissertations.

From 2019 stands out the publication of the $14^{\text {th }}$ issue of Revista de História da Arte: 'The Exhibition: Histories, Practices and Policies' (coordinated by Joana Baião, Leonor de Oliveira and Susana M. Martins), a thematic issue that approaches the 'exhibition' as an object of study, enabling several research questions. Written entirely in English and drawing from a wide array of external contributions, it also illustrates the Institute's 
option for internationalization in this domain. Also related to internationalization, is the investment on building a space for reflection around the history and contemporary challenges of museology in the Iberian and Iberian American space, of which the four editions of the Fórum Ibérico de Investigação em Museologia are symptomatic. ${ }^{32}$ In this context results, for example, the digital publication of the minutes of the second edition of the Forum that took place in Lisbon (2018): Os Museus e a(s) Sociedade(s): Teorias, Contextos, Histórias, Experiências, Desafios. II Fórum Ibérico de Investigação em Museologia (Baião and Silva 2019).

An affirmation of the museum studies line of research of the Institute, on the other hand, is embodied in projects such as Fontes para a História dos Museus de Arte em Portugal (2010-2013), with the scientific coordination of Raquel Henriques da Silva (see Soares, Baião and Oliveira 2013) and the Dicionário Quem é Quem na Museologia Portuguesa (see Ferreira, Monteiro and Silva 2019), the latter adopting the biographic genre for a better understanding of the history of Portuguese museums and museology.

In the case of Universidade do Porto, this (re)positioning can be seen, for example, in the creation of the series Ensaios e Práticas em Museologia (in digital format exclusively), started in 2011 by Alice Semedo, then coordinator of masters' studies in museology at this university. This series is a yearly publication that still remains. ${ }^{33}$ Most of the articles included in the first edition resulted from masters' dissertations presented in 2008 and 2009 in this university (although not exclusively), thereby affirming a diversified and expanding field of study, as stated by the first issue's coordinators:

The various texts quite illustrate the diversity of research topics in museology, while as a whole they materialize several views and directions in contemporary museology. They define a territory of professionals-in-action while promoting spaces for reflection and critical discussion. (Semedo and Costa 2011,4)

The emergence of this series must also be seen as an element of continuity in the dynamics launched by this university in 2009, when it organized the first Seminário de Investigação em Museologia dos Países de Língua Portuguesa e Espanhola (SIAM) which took place in October 12-14 at Fundação Dr. António Cupertino de Miranda (Porto). The creation of a space for reflection, promotion and dissemination around museum studies, open to Portuguese and Spanish-speaking researchers, called for the development of a 'community of practice' which, going beyond the national context, intended to explore the potential for reflection and cooperation among professionals and researchers who, despite their different geographical origins, share interests in common.

Well aware of the research gaps in this area in Portugal, and of the urgent need to facilitate the creation of critical and collaborative spaces for training and research, this Seminar sought, above all, to contribute to a community of practice involving researchers coming from Portuguese- and Spanish-speaking countries. Thus, in addition to deeper reflection and research practices in museology, this Seminar aimed at actively helping to construct a community of practice that would support the discussion and development of shared projects. (Semedo and Nascimento 2010, 8)

This discussion forum led to the publication of three volumes containing the minutes, in a collaborative scheme that was continued in the following years (2010 in Buenos Aires and 2011 in Madrid).

The case of Universidade Lusófona de Humanidades e Tecnologias also illustrates the (re)positioning mentioned above. In 2013 the Cadernos de Sociomuseologia, a journal that 
goes back to 1993, began a new series in digital format, seeking to conform to international guidelines for scientific journals. This implied reshaping the editorial process, so as to meet the requirements of indexation and accreditation - a reformulation that can be connected to changes promoted at the national level, as we have seen. Under the direction of Mário Moutinho and Judite Santos Primo, this journal is fundamentally aimed at disseminating texts by students and teachers - both Portuguese and Brazilian - involved in post-graduation courses in museology (masters' and doctorate) offered by this university. It combines a very uneven mix of texts theses, essays, minutes, and compilations - which globally feed a network established around the training cycles, assuming a rather endogamic tone. The orientation of the contents, although diverse when seen globally, follows a general emphasis on the social role of museums. This approach has been assumed by the university, under the neologism 'Sociomuseology', by inheriting and reframing the principles promoted by the 'New Museology' (Nouvelle Muséologie) of the 1970's and 80's, whose repercussions were felt in Portugal as well (Carvalho 2015).

\section{MIDAS - an inter-university initiative}

MIDAS - Museus e Estudos Interdisciplinares appeared in 2013. It is an exclusively digital journal, dedicated to the study of museums as a field of work and interdisciplinary reflection. It is biannual, with peer review and open access. ${ }^{34}$ This project is an interuniversity initiative, founded by Alice Semedo (Universidade do Porto), Paulo Simões Rodrigues (Universidade de Évora), Pedro Casaleiro (Universidade de Coimbra), Raquel Henriques da Silva (Universidade Nova de Lisboa) and Ana Carvalho (Universidade de Évora), bringing together representatives from the leading Portuguese universities that promote training and research in museology.

An international approach is assumed, favouring a relationship of proximity and dialogue with Portuguese- Spanish-speaking countries and also the adherence to international criteria and standards regarding scientific journals - namely the practice of indexation into national and international databases. This journal was inserted, from the moment it was founded, into the French platform for scientific publications OpenEdition journals - which reflects the assumption and sharing of international standards.

51 Journals such as MIDAS seem to affirm a community of practice and research in the museum studies field. ${ }^{35}$ Furthermore, the creation of a periodical along these lines also demonstrates the existence of a critical mass, propelled by research produced via doctoral studies in this area, and more recently post-doc studies within the supporting framework of the Portuguese Foundation for Science and Technology. On the other hand, the impossibility of a career in museums, due to the scant entry of new museum professionals into the public service, a situation which has become chronic in recent years, is also a factor that cannot be ignored in this context, and that has contributed, in a way, to leverage the development of research projects as an alternative route to a connection to the world of museums. 


\section{Dissemination of academic research: the publication of theses}

52 The publication of dissertations has been one way of increasing the dissemination of knowledge generated by academic reflection. In the case of museum studies, such initiatives have been, generally speaking, scarce and dispersed. This context adds importance to the role of the series Textos Universitários de Ciências Sociais e Humanas, an initiative of Fundação Calouste Gulbenkian and Fundação para a Ciência e a Tecnologia. ${ }^{36}$ This has enabled the publication of some doctoral theses in museology, originating in different universities, where a wide range of studies on the history of museums and museology stand out. ${ }^{37}$ This initiative, however, was discontinued in 2011.

53 The collection Estudos de Museus, created in 2015, brought a new dynamic in this domain. One of the reasons for this initiative was the increase in the number of doctoral theses in this area, and the need to make them better-known beyond the more restricted circles of academia. The collection aims to bring academic reflection closer to a wider spectrum of readers and communities of practice. The editorial project is led by DGPC (the cultural heritage authority) in partnership with the publisher Caleidoscópio, which among other things ensures distribution in the marketplace. The collection seeks to publish theses in which the subject matter relates to museums under the tutelage of DGPC, as well as others, or about contemporary topics in museology. Although there is no public call for proposals, or a public set of rules, the yearly selection process is supported by an external editorial committee, composed of representatives from various Portuguese universities ${ }^{38}$. DGPC provides financial support, conducts the process and the editorial review, the latter under the responsibility of Clara Frayão Camacho (from Departamento de Museus, Conservação e Credenciação). Totalling 18 titles published in printed form, the chosen themes cover topics around the history of museums and museology, including the history of collections formation, individual collectors and museum related personalities, and aspects of contemporary museology (e.g. museum networks and accreditation, accessibility, mediation and creativity, cultural diversity, technologies, among others).

\section{Normalization and professionalization of procedures: the technical publications}

On a brief note, we underline the editorial dynamics promoted by those government organisations with responsibility for museums - especially from the late 1990's to the 2010's - toward the publication of technical reference works for the sector. A case in point is the series 'Temas de Museologia', which includes publications on topics focusing on accessibility (Mineiro 2004), circulation of cultural goods (Carvalho 2004) and preventive conservation (Camacho 2007), as well as the publication of several titles on inventory from the series Cadernos de Normas de Inventário. These editorial lines which demonstrated a commitment to invest in the professionalization and normalization of procedures in the museum sector, by disseminating resources, good practices, and guidelines - would end up lacking further development within the institutional framework of DGPC (2012-). 


\section{Conclusion} extent, from the entry of museology into the world of universities, through advanced training at several levels. This is also supported via research centers in the area of social sciences and humanities, a context that provided and boosted the museum as an object of study, in an exercise of greater freedom of research and scientific creation. Apparently, this positioning has been more accentuated in the last decade, following the development of programs at the doctoral level and postdoctoral studies, showing a differentiation process in order to reinforce and give visibility to the scientific production of researchers. On the other hand, within the framework of a national scientific policy, research contracts and projects funded through competitive calls by FCT are not to ignore, with an emphasis on stimulating competitiveness, evaluation and the need to more definition in strategic programs of the respective research centers. This is an aspect that may imply the definition of consequent lines of research, particularly in the context of museum studies, a situation that, in general, has not been achieved in the past, despite some signs in this direction. Internationalization is another aspect that is beginning to be developed, as examined in the case of Universidade Nova and Universidade do Porto, through initiatives aimed at building bridges, spaces for reflection and proximity in the Iberian and Iberian American space. In addition, internationalization also appears, in the context of compliance with international scientific policy standards, as an element of influence, as evidenced in recent years by the requirement for international evaluation panels in national calls for the Stimulus of Scientific Employment or project grants, in which applications for projects in the area of museums and museology are included.

57 The growth of museum studies has also been strengthened with the contribution of official government organizations in the area of museums and heritage, with responsibilities in matters of policymaking. At this institutional level a trajectory of specialization seems evident, first with the creation of Instituto Português de Museus and then within the framework of the Instituto dos Museus e da Conservação, creating conditions for the construction of a space for debate and reflection around the challenges of museums and museology on a national scale. Editorial projects such as the journal museologia.pt (2007-2011) and the Boletim da Rede Portuguesa de Museus (2001-2011), as well as the edition of technical publications reveal these dynamics and a specialization path within public policies. However, with the extinction of the IMC and the creation of a new institutional structure - the DGPC, with multiple sectors of intervention (architectural and archaeological heritage, museums, conservation and restoration, and cultural heritage - tangible and intangible), the specialization cycle has started to fade, to some extent. In this respect, when opting for a more generalist model of institutional scope, to which has added an adverse context in terms of funding, it ended up resulting in a lesser emphasis on museums, with several impacts (Camacho 2020), namely in the field of publishing, as we argue.

The creation of mechanisms that encourage the dissemination of knowledge generated by academic reflection among the community of practice in museums is still a 
challenge. Initiatives such as the collection Estudos de Museus (2015-) by DGPC confirms the commitment to a more fruitful relationship between academia and the world of museums, but it does not fully resolve the latent tension between the two universes. This tension is identified both in the context of training and in the development of research projects, namely the tendency (at least in rhetorical terms) toward a more cross-cutting and dialogical commitment between theoretical and practical problems, in the perspective that empirical knowledge and theory can feed off and shape each other.

In addition to the contribution of universities and official museum and heritage institutions, another element of the internal architecture of different actors examined in this exploratory study corresponds to the editorial initiatives emanating from the community of practice itself, whether through museums or professional associations. At this point, the challenge, with particular evidence in the case of associations, lies in the interdependence relationship with the voluntarism that characterizes these associative movements and their leadership cycles, conditioning or enhancing the reach of editorial projects. Museum professionals form a multivocal and heterogeneous community, with a professional identity also under construction and negotiation (Semedo 2002). In this context, is not to ignore the role and contribution of developing a body of specific knowledge through universities with possible implications for the valorisation and professionalization of this community (Semedo 2002).

The mapping traced over three decades of museum studies revealed important structural changes and significant growth, pointing out dynamics, relations, points of contact and trends, a field that is still evolving and affirming itself. It is hoped that this empirical and exploratory approach to publications in museum studies, even though it is only one of the dimensions of the multifaceted trajectory of the history of this field, can generate future reflections and new perspectives for understanding its trajectory. In this context, arise a number of questions. It would be of interest to investigate the evolution of university programs and curricula in museology as a result of the multiple transformations over the last years. How does this apparent tendency to reframe museology courses for broader areas, namely for 'heritage management' (Lorente 2012) is marking the Portuguese panorama? What implications does it have for curricular plans and the definition of knowledge and skills? And, on the other hand, what direction have research projects in this area taken, which approaches are valued or underestimated?

Acknowledgments

61 This work is funded by national funds through the Foundation for Science and Technology and by the European Regional Development Fund (ERDF) through the Competitiveness and Internationalization Operational Program (POCI) and PT2020, under the project UID/HIS/00057/2013 (POCI-01-0145-FEDER-007702). I would like to thank Clara Frayão Camacho, Maria de Fátima Nunes and Raquel Henriques da Silva for reading the manuscript and making valuable comments. I also wish to extent my tanks to peer reviewers' suggestions. 


\section{BIBLIOGRAPHY}

Baião, Joana, and Raquel Henriques da Silva, eds. 2019. Os Museus e a(s) Sociedade(s): Teorias, Contextos, Histórias, Experiências, Desafios. II Fórum Ibérico de Investigação em Museologia. [Lisboa]: Instituto de História da Arte, Faculdade de Ciências Sociais e Humanas, Universidade Nova de Lisboa.

Brigola, João Carlos. 2003. Colecções, Gabinetes e Museus em Portugal no Século XVIII. Textos Universitários de Ciências Sociais e Humanas. Lisboa: Fundação Calouste Gulbenkian, Fundação para a Ciência e a Tecnologia.

Brigola, João Carlos. 2016. "A Investigação em História da Museologia: O Estado da Arte. As três 'Idades' da Historiografia do Coleccionismo e dos Museus na Tradição Intelectual do Ocidente.” In Museus, Património e Ciência. Ensaios de História da Cultura. Biblioteca - Estudos \& Colóquios, 6-16. Évora: Publicações do CIDEHUS. http://books.openedition.org/cidehus/97

Camacho, Clara Frayão, coord. 2007. Plano de Conservação Preventiva: Bases Orientadoras, Normas e Procedimentos. Temas de Museologia. Lisboa: Instituto dos Museus e Conservação.

Camacho, Clara Frayão. 1999. "Renovação Museológica e Génese dos Museus Municipais da Área Metropolitana de Lisboa: 1974-90”. Dissertação de mestrado em Museologia e Património, Universidade Nova de Lisboa.

Camacho, Clara Frayão. 2001. "Editorial." Boletim Trimestral da Rede Portuguesa de Museus 1 (Jun.): $1-2$.

Camacho, Clara Frayão. 2007. “Editorial.” Museologia.pt 1 (May): VI-VII.

Camacho, Clara Frayão. 2020. Grupo de Projeto Museus no Futuro: Relatório Final. Grupo de Projeto Museus no Futuro, Direção-Geral do Património Cultural. http://hdl.handle.net/10174/28464

Carvalho, Ana, and Alexandre Matos. 2018. "Museum Professionals in a Digital World: Insights from a Case Study in Portugal." Museum International (Special Issue: Museums in a Digital World), 70 (277-278): 34-47.

Carvalho, Ana. 2013. "Museologia, entrevista com Filipe Themudo Barata." Blog No Mundo dos Museus. 4.03-2013. https://nomundodosmuseus.hypotheses.org/5159

Carvalho, Ana. 2015. “Decifrando Conceitos em Museologia: Entrevista com Mário Moutinho." Museologia \& Interdisciplinaridade 4 (8): 252-69.

Carvalho, Ana. 2017. “A Construção de uma Comunidade de Prática e de Investigação em Museologia: O Papel das Publicações.” Cadernos do Museu 5 (Jan.): 32-45.

Carvalho, Ana. 2019. “Em Torno da Definição de Museu do ICOM: Lições a Partir de Quioto." património.pt (Nov.). https://www.patrimonio.pt/post/em-torno-da-definição-de-museu-doicom-lições-a-partir-de-quioto

Carvalho, Anabela, coord. 2004. Circulação de Bens Culturais Móveis. Temas de Museologia. Lisboa: Instituto Português de Museus.

Law-Decree n. 55/2001, Diário da República, 15 February, 2001.

Delicado, Ana. 2009. A Musealização da Ciência em Portugal. Textos Universitários de Ciências Sociais e Humanas. Lisboa: Fundação Calouste Gulbenkian, Fundação para a Ciência e a Tecnologia. 
Desvallées, André, and François Mairesse. 2010. “Museology (Museum Studies).” In Key Concepts of Museology, 53-56. Paris: Armand Colin.

Faria, Maria Alice. 1985. “Palavras Prévias.” Bibliotecas, Arquivos e Museus, vol. 1: 1 (Jan.-Jun.): 12.

Ferreira, Emília, Joana d'oliva Monteiro and Raquel Henriques da Silva, coord. 2019. Dicionário Quem é Quem na Museologia Portuguesa. Lisboa: Instituto de História da Arte da Faculdade de Ciências Sociais e Humanas da Universidade Nova de Lisboa.

Fyfe, Gordon. 2006. "Sociology and the Social Aspects of Museums." In A Companion to Museum Studies, ed. Sharon Macdonald, 33-49. Malden: Blackwell.

Garrido, Álvaro. 2015. “Editorial.” Argos 3 (Oct.): 5.

Gil, Fernando Bragança. 1991. "Ensino em Museologia: A Situação em Portugal.” Ethnologia (Actas do 1.ํㅡㄴ Encontro Universitário Luso-espanhol sobre a Investigação e o Ensino na Área de Museologia, Cascais, 27 e 28 de Maio de 1988), n. 6 (Jul.-Dec.): 23-35.

Gouveia, Henrique Coutinho. 1991 (1986). “Os Museus e a Universidade, Investigação e Ensino.” Ethnologia (Actas do 1.ํㅡㄹ Entro Universitário Luso-espanhol sobre a Investigação e o Ensino na Área de Museologia, Cascais, 27 e 28 de Maio de 1988), n. 6 (Jul.-Dec): 199-209.

Gouveia, Henrique Coutinho. 1991. "Museologia e Antropologia: Ensino e Investigação no Departamento de Antropologia da Universidade Nova de Lisboa." Ethnologia (Actas do 1. ${ }^{\circ}$ Encontro Universitário Luso-espanhol sobre a Investigação e o Ensino na Área de Museologia, Cascais, 27 e 28 de Maio de 1988), n. 6 (Jul.-Dec): 53-65.

Guedes, Natália Correia. 2009. Elementos para a História da Comissão Portuguesa do ICOM: 15 anos de Actividade, 1986-2001. https://icom-portugal.org/wp-content/uploads/2015/03/HistoriaICOM-1986-2001-Guedes.pdf

Lacerda, Manuel. 2013. “Editorial.” RP - Revista Património 1 (Nov.): 1.

Lorente, Jesús-Pedro. 2012. “The Development of Museum Studies in Universities: From Technical Training to Critical Museology.” Museum Management and Curatorship 27 (3): 237-52.

Lorente, Jesús-Pedro. 2013. "Las Revistas Museológicas en la Actualidad: Una Panorámica Global.” MIDAS - Museus e Estudos Interdisciplinares 1.

Luís Soares, Joana Baião and Leonor Oliveira. 2013. "Fontes para a História dos Museus de Arte em Portugal: Um Projeto, Muitos Projetos...." MIDAS - Museus e Estudos Interdisciplinares 2.

Macdonald, Sharon. 2006. “Expanding Museum Studies: An Introduction.” In A Companion to Museum Studies, ed. Sharon Macdonald, 1-12. Malden: Blackwell.

Mairesse, François. 2016. “Introduction.” In Nouvelles Tendances de la Muséologie, ed. François Mairesse, 13-26. Paris: La Documentation française.

Mineiro, Clara, ed. 2004. Museus e Acessibilidade. Temas de Museologia. Lisboa: Instituto Português de Museus.

Mota, Maria Manuela Soares de Oliveira. 2005. “A Nossa História. Uma Visão muito Pessoal da Antiga Presidente da APOM (1974-1991).” https://apmuseologia.org/about/a-nossa-historia/

Nolasco, Maria da Luz. 2000. “Una Ruta Ibérica para el Futuro.” In RdM. Revista de Museología (Museos y Museología em Portugal: Uma Ruta Ibérica para el Futuro), Extra 1: 8-9.

Nunes, Maria de Fátima. 2001. Imprensa Periódica Científica: Leituras de «Sciencia Agricola» em Portugal. Lisboa: Estar Editora. 
Oliveira, Ernesto Veiga de. 1971. Apontamentos Sobre Museologia e Museus Etnológicos: Lições Dadas no Museu de Etnologia do Ultramar. Estudos de Antropologia Cultural, 6. Lisboa: Junta de Investigações do Ultramar, Centro de Estudos de Antropologia Cultural.

Pereira, Benjamin. 1989. “Ernesto Veiga de Oliveira e o Museu de Etnologia.” In Estudos em Homenagem a Ernesto Veiga de Oliveira, org. Fernando Oliveira Baptista, et al., 555-568. Lisboa: Instituto Nacional de Investigação científica, Centro de Estudos de Etnologia.

Pereira, Manuela Cantinho. 2005. O Museu Etnográfico da Sociedade de Geografia de Lisboa: Modernidade, Colonização e Alteridade. Textos Universitários de Ciências Sociais e Humanas. Lisboa: Fundação Calouste Gulbenkian, Fundação Para a Ciência e a Tecnologia.

Pimentel, Cristina. 2005. O Sistema Museológico Português (1833-1991): Em Direcção a um Novo Modelo Teórico para o seu Estudo. Textos Universitários de Ciências Sociais e Humanas. Lisboa: Fundação Calouste Gulbenkian, Fundação para a Ciência e Tecnologia.

Porto, Nuno. 2009. Modos de Objectificação da Dominação Colonial: O Caso do Museu do Dundo, 1940-1970. Textos Universitários de Ciências Sociais e Humanas. Lisboa: Fundação Calouste Gulbenkian, Fundação para a Ciência e a Tecnologia.

Raposo, Luís. 2014. “O Papel do Associativismo na Construção de uma Política Democrática de Museus." Ciências e Técnicas do Património, Revista da Faculdade de Letras XIII: 261-74.

Rocha-Trindade, Maria Beatriz. 1993. “O Porquê e o Como.” In Iniciação à Museologia, coord. Maria Beatriz Rocha-Trindade, 17-18. Lisboa: Universidade Aberta.

Sandahl, Jette, ed. 2019. “The Museum Definition: The Backbone of Museums.” Museum International (special issue) 71 (1-2).

Santos, David. 2018. [Editorial]. RM - Revista de Museus 1 (Dec.): 5.

Semedo, Alice, and Elisa Noronha Nascimento, coord. 2010. “Apresentação.” In Actas do I Seminário de Investigação em Museologia dos Países de Língua Portuguesa e Espanhola, 8-9. Vol. 1. Porto: Universidade do Porto.

Semedo, Alice, and Patrícia Costa, eds. 2011. “Apresentação.” In Ensaios e Práticas em Museologia, 4. Porto: Universidade do Porto.

Semedo, Alice. 2002. "The Professional Museumscape: Portuguese Poetics and Politics.” PhD, Department of Museum Studies, University of Leicester.

Semedo, Alice. 2004. "Estratégias Museológicas e Consensos Gerais.” In Museus do Eixo Atlántico, coord. Mário Brito and José Cuñarro, 5-32. Vigo: Eixo Atlántico.

Semedo, Alice. 2013. “Formação em Museologia: Círculos e Outras Geometrias.” Anais do Museu Paulista 21 (1): 49-62.

Shiele, Bernard. 2012. "La Muséologie: Un Domaine de Recherches." In La Muséologie, Champ de Théories et des Pratiques, ed. Anik Meunier, 79-100. Québec: Presses de l'Université du Québec.

Silva, Raquel Henriques da. 1999. "Sessão de Abertura." In 9. Encontro Nacional Museologia e Autarquias 1998 Loures. Actas, 14-18. Loures: Câmara Municipal de Loures.

Silva, Raquel Henriques da. 2000. “Apresentação.” In Inquérito aos Museus em Portugal, ed. Instituto Português de Museus, 11-17. Lisboa: Instituto Português de Museus.

Vaquinhas, Irene. 2013. “A Museologia como Campo de Estudo nas Universidades Portuguesas: Esboço de Evolução, Pertinência e Atualidade.” MIDAS - Museus e Estudos Interdisciplinares 1. 


\section{NOTES}

1. This is an augmented and revised version of a previous text in Portuguese: A Construção de uma Comunidade de Prática e de Investigação em Museologia: O Papel das Publicações (Carvalho 2017). All translations of Portuguese quoted texts are mine.

2. About the different meanings of the term 'museology' see Desvallées and Mairesse (2010).

3. When ICOFOM (International Committee for Museology) was created within the ICOM (International Council of Museums) in 1977, one of its aims was to establish museology as a university scientific discipline (Mairesse 2016). About the history of museology see Shiele (2012).

4. About the relation, still problematic, between theory and practice in museology see Semedo (2013).

5. Nevertheless, precursor initiatives for teaching museology in universities are known even before World War II (see Lorente 2012).

6. For a more detailed view on the history of museology training in universities, see Lorente (2012).

7. Even before the creation of postgraduate courses and master's degrees in universities, the teaching of museology had already been introduced in curricula plans of graduation (licenciatura) courses. This is the case of the graduation course in 'Anthropological and Ethnological Sciences' at Instituto Superior de Ciências Sociais e Política Ultramarina, where the teaching of museology was introduced in 1970-1971 (then interrupted between 1973-1974). In this context, it is worth noting the role of the ethnologist Ernesto Veiga de Oliveira (1910-1990), who coordinated the Museu de Etnologia (Lisbon) between 1965 and 1973. The museology teaching was initially introduced by the anthropologist Jorge Dias (1907-1973), but Veiga de Oliveira was in charge of the regency of the chair and its development (Pereira 1989). The chair contents were published by Veiga de Oliveira in 1971 in the sixth issue of the collection Estudos de Antropologia Cultural, configuring a work of relevance not only for the contents but also for its novelty in the scarce panorama of specialized literature on museology at the time in Portugal. Furthermore, from 1981-1982, a chair in 'Museology (applied to museums of ethnology)' was taught in the graduation course in Anthropology at the Faculdade de Ciências Sociais e Humanas da Universidade Nova de Lisboa (Gouveia 1991, 58-61). It is also worth mentioning, at the same time, the existence of museology teaching in graduation courses of Painting and Sculpture at the Escola Superior de Belas Artes de Lisboa (Gil 1991).

8. Museum professionals training was framed in legislation since 1932 (updated in 1953), being provided by the Museu Nacional de Arte Antiga (MNAA) with a three-year training. Between 1965 and 1974 it was reformulated into a two-year training, with a theoretical component provided by the Faculdade de Letras da Universidade de Lisboa and a practical training under the responsibility of MNAA (Brigola 2016 (2004)).

9. For the academic year 2010-211 Vaquinhas (2013) identified an offer of 12 courses in museology at the postgraduation and mater's levels at public and private Portuguese universities, an asymmetric number considering the scale of the country. However, for the academic year 2016-2017 we can observe a more reduced offer with seven active master's courses in museology (Carvalho and Matos 2018). A more up-to-date analysis of the training offer would be relevant to understand the changes that have taken place.

10. Dominique Ferriot (Musée des Arts et Métiers, Paris), Henrique Coutinho Gouveia (Universidade Nova de Lisboa), Henrique Lins de Barros (Museu de Astronomia e Ciências Afins, Rio de Janeiro), João Brigola (Universidade de Évora), John Durant (At-Bristol), José Moreira de Araújo (Museu de Ciência da Faculdade de Ciências do Porto), Mário Pereira (Instituto Português de Conservação e Restauro, Lisboa), Natália Correia Guedes (Universidade Nova de Lisboa), Victor Gil (Exploratório Infante D. Henrique, Coimbra), and Wolf Peter Fehlhammer (Deutsches Museum, München). 
11. In the institutional field, for the 1980's, should be mentioned the edition, albeit ephemeral, of the journal Bibliotecas, Arquivos e Museus (1985-1987) by the Instituto Português do Património Cultural (1980-1989). In the first issue of the journal, in 1985, Maria Alice Faria, then director of Departamento de Museus, Palácios e Fundações of this Institute, underline: 'The journal that is now starting its publication [...] will dedicate a relevant part of its space to the issue of museums, thus filling a serious gap and contributing to a wide and open exchange of ideas. [...] Anyone interested in museological sciences will be able to count on a vehicle for technical and scientific expression that the BAM journal intends to be' (Faria 1985, 12). The journal was directed by Fernando Bandeira Ferreira (1921-2003). For the same period, mention should be made to the publication of Património e Museus Locais, edited by the Instituto Rainha Dona Leonor, which continued in the 1990's (Camacho 2007).

12. Editorial members: Alice Semedo (Faculdade de Letras da Universidade do Porto), Graça Filipe (Ecomuseu Municipal do Seixal), João Brigola (Universidade de Évora), João Castel-Branco (Museu Gulbenkian and ICOM Portugal), Luís Raposo (Museu Nacional de Arqueologia) and Raquel Henriques da Silva (Faculdade de Ciências Sociais e Humanas da Universidade Nova de Lisboa).

13. The topics developed in each issue were as follows: 'museums and architecture' (2007); 'museums management' (2008); 'museums and technological innovation' (2009); 'science museums' (2010); and 'national museums' (2011).

14. Journal edited by the former Instituto Português do Património Arquitectónico e Arqueológico - IPPAR, and later called Instituto de Gestão do Património Arquitectónico e Arqueológico - IGESPAR; 2001-2011.

15. The journal does not assume publicly an external editorial or scientific committee to support articles peer review.

16. The themes selected for each issue: 'heritage and rehabilitation' (2013); 'heritage management' (2014); 'cultural heritage and communication' (2015); 'heritage and society' (2016); heritage challenges (2017-2018); and 'heritage and sustainability' (2019).

17. Adelaide Duarte, Graça Filipe, José Soares Neves, Manuel Bairrão Oleiro, Marta C. Lourenço, Rita Macedo and Rui Parreira.

18. The first issue: 'museums and tourism' (2018); and the second issue: 'museums and digital society' (2019).

19. The last three issues of the bulletin (2010-2011) were coordinated by Isabel Victor, who in 2010 took on the position of director of the Departamento de Museus do Instituto dos Museus e da Conservação, including responsibilities in coordinating the RPM.

20. Is not to ignore the editorial action of APOM in the $20^{\text {th }}$ century. Founded in 1965 , it is worth noting the creation of the association's bulletin in 1967 ( $\mathrm{Nr} 1$ ), even though it had no continuity; and the periodical Apom Informações (1973-1984), under the direction of Fernando Bragança Gil. This journal was later replaced by a bulletin framed by a joint initiative between APOM and ICOM, and by Cadernos de Museologia (Mota 2005). It is also worth mentioning the publication of minutes of APOM Colloquia (Colóquios da APOM), among other initiatives, over the last decades of the $20^{\text {th }}$ century.

21. ICOM Portugal statutes date from 1975 (Guedes 2009), however, the first steps to create the association date back to 1952 (Raposo 2014).

22. This new series is linked to a new direction of ICOM Portugal under the leadership of Luís Raposo, between 2008 and 2014.

23. This bulletin series is also marked by a new board in the association, chaired by José Alberto Ribeiro (2014-2020).

24. 'Museums and management: new bridges to society' (2014); 'networks' (2015); 'museums for a sustainable society' (2015); 'industrial and technical heritage' (2015); 'museums and cultural diversity' (2016); 'museums and cultural landscapes' (2016); 'UNESCO Recommendation concerning the Protection and Promotion of Museums and Collections' (2016); 'museum 
management and museum policy' (2017); 'museums and contested histories: saying the unspeakable in museums' (2017); 'Portuguese Museum Act (Lei-Quadro dos Museus Portugueses): state of the art and perspectives' (2017); 'hyperconnected museums: new challenges and perspectives' (2018); and 'museum professionals, new competences?' (2018).

25. In July 2020, ICOM Portugal restarted to publish the bulletin, with the coordination of Sofia Marçal, the first issue of the new board, chaired by Maria de Jesus Monge, elected in March 2020. 26. Scientific committee members: António Nabais, Clara Camacho, Cláudio Torres, Dália Paulo, Graça Filipe, Hugues de Varine, João Alpuim Botelho, José d'Encarnação, José Gameiro, Pedro Prista and Rui Parreira.

27. In addition to Portuguese, it publishes texts written in English, French and Spanish.

28. In the past, should be mentioned the existence of periodicals edited by the Museu Nacional de Arte Antiga, in two series: Boletim dos Museus Nacionais de Arte Antiga (1939-1943) and Boletim do Museu Nacional de Arte Antiga (1944-1969).

29. Although recognizing the importance of catalogues in the production of knowledge about museums and collections, in this article we chose not to develop this topic further since it would require a more specific and in-depth analysis.

30. For the academic year 2020-2021are available at least three doctorate courses related to museology: Universidade Lusófona ('Museology'), Universidade de Évora ('History and Philosophy of Science, specialization Museology') and Universidade Nova de Lisboa ('Art History, specialty in Museology and Artistic Heritage'). The doctoral course in 'Anthropology: Policies and Images of Culture and Museology' (ISCTE-Instituto Universitário de Lisboa and Universidade Nova de Lisboa) had two editions, in 2013 and 2015, but there was no edition in 2020-2021: https://ielt.fcsh.unl.pt/antropologia-politicas-e-imagens-da-cultura-e-museologia/ (accessed December 9, 2020). It should be noted that the doctorate course in museology at the Universidade do Porto was reformulated and is since 2016 a doctorate in 'Heritage Studies', with three possibilities of specialization: 'Archaeology', 'Art History' and 'Museology'.

31. However, it should be noted that before of the creation of doctorate courses in museology, doctoral theses had been produced in this area since the 1990's, both in Portuguese academic contexts and abroad.

32. I Foro Ibérico de Jóvenes Investigadores (2017, Museo Nacional de Escultura, Valladolid) (see Bolaños Atienza and Arnaldo 2019); II Fórum Ibérico de Investigação em Museologia (2018, Museu Nacional de Arte Antiga and Faculdade de Ciências Sociais e Humanas da Universidade Nova de Lisboa); III Foro Ibérico de Estudios Museológicos (2019, Museo Arqueológico Nacional, Madrid); and IV Fórum Ibérico de Estudos Museológicos (2020, Faculdade de Belas-Artes da Universidade do Porto).

33. It should be noted that before the series Ensaios e Práticas em Museologia, the publication of articles based on studies developed at the Universidade do Porto was also disseminated through the journal Ciências e Técnicas do Património (2002-2014).

34. The journal Vox Musei, Arte e Património, created in 2013, should also be mentioned. However, since it is a Brazilian initiative journal (Universidade Federal do Piauí) we did not consider it in the context of this analysis. Nonetheless, its genesis includes the collaboration of a Portuguese partner: the CIEBA - Centro de Investigação e de Estudos em Belas Artes da Universidade de Lisboa, throutgh Fernando António Baptista Pereira. After 2013, the year in which two issues are published, a hiatus follows until 2016, with two issues published that year, with no further evidence of published titles after that (https://revistas.ufpi.br/index.php/voxmusei/issue/ archive). The journal is coordinated by Áurea Paz Pinheiro (Universidade Federal do Piauí).

35. It does not mean, however, that previously articles about museology and museums were not published in scientific journals, namely in established disciplinary areas such as Anthropology, Sociology, History, among others.

36. This initiative consisted of a public call for proposals, comprising a public notice, its own regulation and a selection process by a panel of evaluators. 
37. Among the studies published, the following titles can be highlighted: Colecções, Gabinetes $e$ Museus em Portugal no séc. XVIII (Brigola 2003); O Sistema Museológico Português (1833-1991): Em Direcção a um Novo Modelo Teórico para o seu Estudo (Pimentel 2005); O Museu Etnográfico da Sociedade de Geografia de Lisboa: Modernidade, Colonização e Alteridade (Pereira 2005); A Musealização da Ciência em Portugal (Delicado 2009); and Modos de Objectificação da Dominação Colonial: O Caso do Museu do Dundo, 1940-1970 (Porto 2009).

38. Alice Semedo (Universidade do Porto), Fernando António Baptista Pereira (Faculdade de Belas-Artes da Universidade de Lisboa), Pedro Casaleiro (Universidade de Coimbra), Raquel Henriques da Silva (Universidade Nova de Lisboa) and Vítor Serrão (Universidade de Lisboa).

\section{ABSTRACTS}

In recent decades we have seen the field of museum studies expand. This development has been supported by the contribution of several actors, in various ways. Publications are essential in this process, since they ensure visibility and access to the field of study, while helping to articulate different understandings, proposals and perspectives - both in theory and in practice - thus strengthening its development. This article considers the role of publications in building museology as a field of study in Portugal, especially from the 1990's onwards. This empirical and exploratory study aims to analyse the evolution of publications in terms of contexts, initiatives and actors. While not intending to be exhaustive, we signal some dynamics, relations and trends from recent decades. The methodology adopted includes literature review and is based also on my empirical knowledge on the subject matter. The analysis presented can be significant in contemplating some of the key issues related to the trajectory of museum studies as a field of study over the last three decades.

Assistimos nas últimas décadas à expansão do campo de estudos de museus. Esse desenvolvimento é sustentado com o contributo de diferentes actores e de variadas formas. As publicações são parte fundamental dessa construção na medida em que asseguram a visibilidade e o acesso ao campo de estudos, assim como contribuem para articular diferentes entendimentos, propostas e perspetivas, seja na teorização como na ação, fortalecendo, assim, o seu desenvolvimento. Este artigo analisa o papel das publicações na construção da museologia como campo de estudos em Portugal, com particular evidência a partir da década de 1990. De carácter exploratório, o artigo tem como objectivo analisar a evolução das publicações, em que contextos, iniciativas e actores. Sem a pretensão de um retrato exaustivo, assinalamos algumas dinâmicas, relações e tendências que marcam as últimas décadas. A metodologia adotada incluiu a análise e revisão bibliográfica, e o conhecimento empírico com relação ao tema. A análise apresentada pode ser significativa para compreender algumas das principais questões relacionadas com a construção da museologia como campo de estudo ao longo das últimas três décadas. 


\section{INDEX}

Keywords: museology, museology history, periodical publications - museology, museum studies, scientific journals

Palavras-chave: museologia, história da museologia, publicações periódicas - museologia, estudos de museus, revistas científicas

\section{AUTHOR}

\section{ANA CARVALHO}

Postdoctoral researcher at the Interdisciplinary Centre for History, Cultures and Societies (CIDEHUS) of the University of Évora (Portugal) with a fellowship from the Portuguese Foundation for Science and Technology (FCT). She has a PhD in History and Philosophy of Science, specialization Museology and a Masters degree in Museology. Member of the Task Group Museums of the Future (2019-2020), under the Portuguese Ministry of Culture, to propose recommendations for public policy considering museums sustainability, accessibility, innovation and relevance in society. She collaborated as senior researcher in the Mu.SA project - Museum Sector Alliance (2016-2020). Editor of ICOM Portugal bulletin (2014-2018). Her research interests focus on cultural heritage and museum policies, history of museology and contemporary museology issues.

Centro Interdisciplinar de História, Culturas e Sociedades (CIDEHUS) da Universidade de Évora, Palácio do Vimioso, Largo do Marquês de Marialva, n.o 8, Apartado 94, 7000-809 Évora, Portugal, arcarvalho@uevora.pt 